\title{
"The Princess and the Fisherman" A Comparative Study of Two Francophone Versions of the Story by Vietnamese Author Pham Duy Khiem
}

Harry Aveling

Monash University

\section{Abstract}

The tragic story of My Nuong, the princess, and Truong Chi, the fisherman, is well known and widely loved throughout Vietnam. Although commonly considered to be fully indigenous, this tragic story of "The Princess and the Fisherman" actually derives from a Chinese story first recorded by Feng Menglong (1574-1646). Pham Duy Khiem (1908-1974), a Vietnamese scholar and diplomat, includes it in his Francophone anthology, Légendes des terres sereines (Legends from Serene Lands, 1942) but had first spoken about the tale in a radio broadcast made in France in 1938. This article seeks to introduce the original Chinese narrative and then to compare it with the two versions told by Pham Duy Khiem-a longer version that was the radio broadcast and a shorter, more concise "legend" written in Vietnam in 1942. The article presents for the first time a translation into English of the Chinese source text and of the longer French retelling. It also shows how the length of the radio version of the tale is due to its being aimed at a French audience, with little understanding of or 
sympathy for Vietnam. Finally, it suggests that the tighter narrative and gentle melancholy of the shorter version are an indication of Khiem's growth in confidence as a postcolonial writer.

\section{Keywords}

love sickness, My Nuong, Pham Duy Khiem, Truong Chi, Vietnamese folktales 


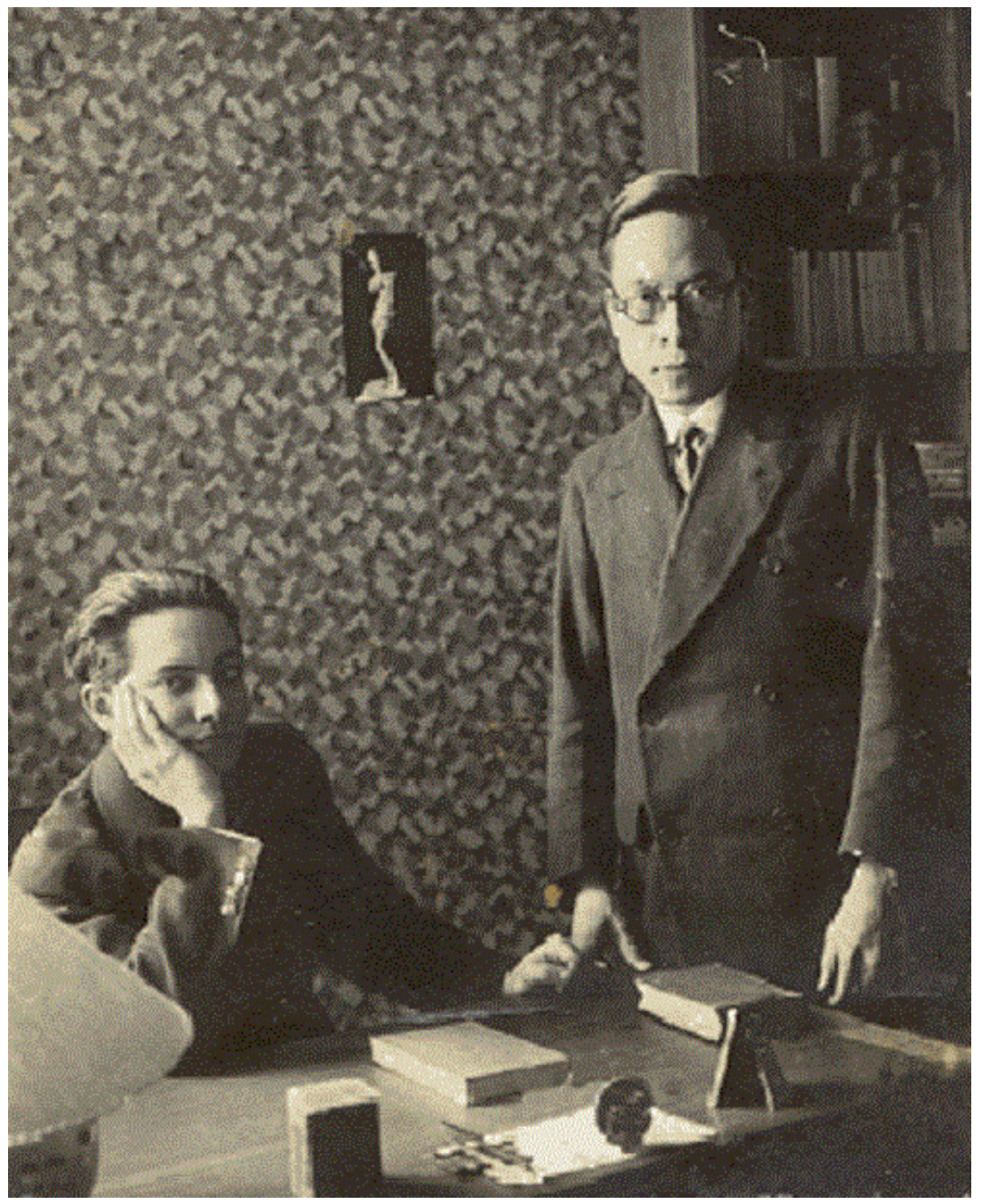

Fig. 1. Phạm Duy Khiêm (right) while studying in France; http://www.phamduy2010.com/ 


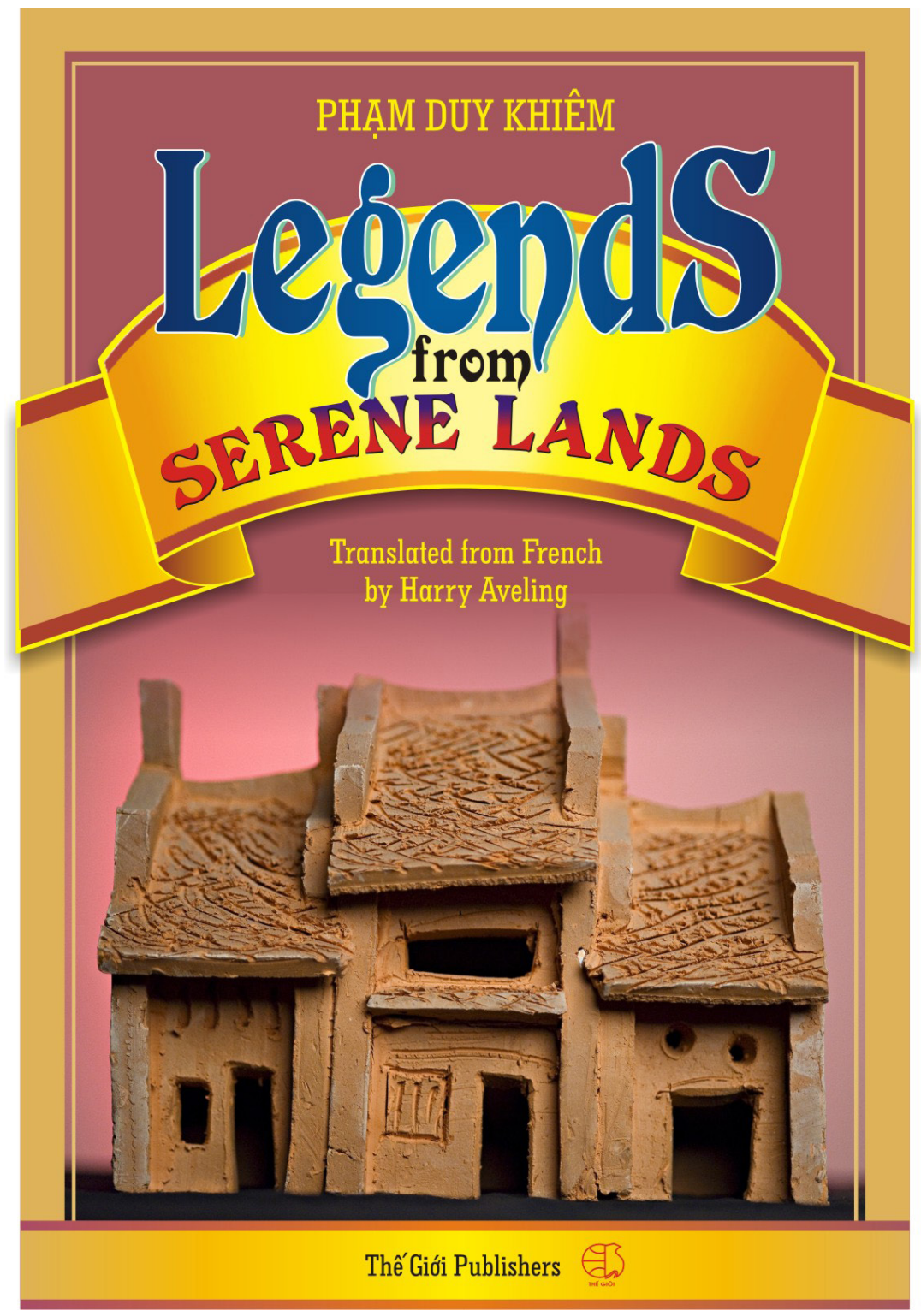

Fig. 2 Cover of Phạm Duy Khiêm's Legends from the Serene Lands: Classical Vietnamese Stories, translated from French by Harry Aveling; http://xunhasaba.com.vn/ 


\section{The Original Chinese Story}

The story which is the seldom recognised origin of the Vietnamese folktale of "The Princess and the Fisherman" was first told by Feng Menglong, a low-level Chinese mandarin at the end of the Ming dynasty (1368-1662). Although he barely passed the national examination at the age of 57, Feng Menglong was also the author of various collections of popular tales told in a simple colloquial style. One of his books, Ch'ing Shi (Stories of Love), is a collection of 841 love stories arranged in 24 chapters. Some of the chapters are loosely arranged into sub-chapters according to their themes. Chapter 11 is undivided and contains 18 entries on the theme of "Transformation." In this chapter, love (ch'ing), especially that between a man and a woman, is innate and sound but also everlasting and elusive. It is sometimes necessary to cast away the human body in order for love to manifest itself more appropriately and concretely. In these eighteen stories, love variously transforms itself into metal, stone, birds, and plants, and even the wind. Stone and metal are symbols of strong will power, determination, and endurance-characteristics of men and women with strong ch'ing. ${ }^{2}$

The particular story which is the origin of the tale of "The Princess and the Fisherman" uses the symbolism of metal to show the strength of the woman's love. The story is in the section that follows.

\section{The Transformation of Iron}

There was once a travelling merchant who was extremely handsome. On one of his trips, he moored his boat by the side of the Xi River. A beautiful young woman lived in a high tower on the riverbank. For about a month, the merchant and the girl constantly gazed at each other and in their hearts they fell deeply in love. However, they were unable to express their love because they were separated by a distance of ten hand lengths and afraid that every eye would look at them and every finger point. Later, when the merchant had sold all his goods, he left. The girl was so full of "love-longing" that she fell ill and died. Her father had the body cremated, but one part of her did not burn. Her heart was not destroyed and turned to iron. Her father took the piece of iron from the ashes and polished it. It showed an image of a boat and a tower facing each other. In the faint distance one could discern human figures. Her father felt very curious and put it away for safekeeping. 
Later the merchant came back again but when he found out that the girl had died, he was very distressed. He asked this way and that and eventually worked out the reasons for the girl's death. He gave the girl's father a gift of money and asked to see the piece of iron. At the sight of the piece of iron, he cried and his tears became blood. The blood dropped onto the iron heart and the heart immediately turned to ash. ${ }^{3}$

\section{Some Vietnamese Versions}

The story is told in Vietnam in a number of different ways. We particularly find it associated with the famous nineteenth century Tale of Kieu, although in a rather allusive manner. In verse 710 , the leading character, Kieu, laments:

No tinh chua tra cho ai

Khoi tinh manh xuong tuyen-daichua tan

The author of one edition of the Tale, Huynh Sanh Thong, translates this verse into English and links it to "a Chinese story":

Till I've paid off my debt of love to him

My heart will remain a crystal down below.

Huynh tells what he describes as the "Chinese story" (source unspecified) in a slightly different way from that of Feng Menglong. In his recollection of the tale, the merchant fails to return for a long time and the girl misses him so much that she dies. The story continues: "When [the girl] was cremated, it was discovered that her heart had turned into a hard rock, like ruby. Upon his return, the merchant wept for the girl. His tears fell on the crystal, and it dissolved into blood" (182n710). The blood and ruby are more graphic than the usual Vietnamese stories; the fact that the metal melts is consistent with them.

Huynh notes that there is also a very different Vietnamese version of the tale (again source unspecified). In this story, the social distance between the couple is greater. The man is a poor boatman, the girl is the daughter of a 
king. The narrative ends with a dramatic twist: unlike the Chinese original, the man dies, not the woman. Huynh says:

[I]n his turn, [the boatman Truong Chi] was smitten with the princess and eventually died of unrequited passion. In the grave, his heart was transformed into a ruby, a blood red 'crystal of love' (khoi tinh), which was later found and fashioned into a drinking cup. The princess received the cup as a present. When she poured tea into it, she saw the reflection of a boatman forlornly rowing his boat. Now realising what she had done to the boatman she wept, and as her tears touched the cup it melted away (182n710).

Another recent version comes from Vo Van Thang and Jim Lawson. Their ending of this story is rather humble: the cup is made of wood, "precious wood" admittedly. The ending is as follows:

One day, [Truong Chi] sang his last song:

Not to be together in this life,

I hope to be with you in the other world.

Then he threw himself into the river and disappeared beneath the silent, flowing water.

His soul entered a tree by the river. It was a tree of precious wood and one day a craftsman cut off a branch to make a set of teacups. The teacups were presented to the father of My Nuong at the time of a festival.

One morning My Nuong poured tea into one of the cups. When she lifted it to drink she saw the image of the fisherman slowly rowing his boat around the bottom of the cup. The sound of his voice came to her ears, loving, regretful and reproaching. A tear from her eye fell into the cup. It shattered into tiny fragments that melted away to nothing (263).

The shape of the Vietnamese stories clearly shows their dependence on Feng Menglong's original but the details change in various ways. The social status of the two main characters varies-the characters may be either a merchant and a woman of high status, or, a princess and a fisherman. In one version the man dies; in the other, the woman dies. The remains of the 
lover's heart can variously become iron, ruby, or wood; all are symbols of resolute and continuing love. In Feng Menglong's version, the iron heart eventually becomes ash; in the Vietnamese versions, it is turned into a cup and finally melts. In all cases, once the offending partner recognises their own fault, some sort of atonement is made and the soul of the other is free to travel on in the afterlife.

\section{Pham Duy Khiem}

The story entitled "Le cristal d'amour" (Love's Crystal) is the first tale included in Pham Duy Khiem's highly regarded anthology, Légendes des terres sereines (1942). Born in Hanoi in 1908, Pham Duy Khiem was a graduate of the leading French schools, the Lycée Albert Sarraut in Hanoi, the Lycée Louis-leGrand in Paris, and the very prestigious Ecole Supérieure Normale in 1935 . He published two collections of folktales, Légendes des terres sereines (1942) and La jeune femme de Nam Xuong (1944), which were both included in a French edition in 1951, similarly entitled Légendes des terres sereines. He also wrote a novel, Nam and Sylvie (1957), which told of the ill-fated love of a Vietnamese student in France for a French girl during the 1930s. Following the war, Pham Duy Khiem became Ambassador of the Republic of (South) Vietnam to France (1954-1957). He died, probably as a result of suicide, in 1957.

Khiem first told the story of the noble woman and the fisherman in a radio broadcast given in France that was later published in Le Monde Illustre, no. 179, May 1938, page 98, entitling it as "Une légende Annamite" ("An Annamite Folktale"). The story is deeply embedded in a commentary aimed at Khiem's French audience. The two versions are presented in translation in the parallel columns (the text of the broadcast has not been published in English translation before) that follow. 
"An Annamite Folktale"

The Radio Broadcast (1938)

The two versions are presented in translation in the parallel columns (the text of the broadcast has not been published in English translation before) that follow.

1 The folktale I am about to tell you is known to all Annamites. I cannot recall when I first read it, I don't even know if I read it or heard it told, but I have loved it for a long time. I have become an old professeur who teaches Greek, Latin and French to young French students like you and to Annamites of your age; I must, to that end, read many books, but of all the beautiful stories gathered along the banks of either the Seine or the Red River, the one I most prefer is the one that I am about to tell you.

2 You need to know that in other times the daughters of high mandarins led a cloistered life, without ever going out, without ever seeing anyone. They did not suffer because things had always been this way and that isolation was part of their very condition.

The young girl of whom I speak had a minister for her father; she lived in a corner of the palace, in a tower, by the side of the river.

3 From her window, she saw only the monotonous rice-fields stretching to the horizon, and on the calm waters the boat of a poor fisherman. The man sang as he worked. From afar, the beautiful young noble woman could not see his face, she could scarcely distinguish his movements, but she listened to his voice as it rose up to where she was. Every day, she listened to him. His voice was beautiful, but the song was sad.

2 There was once, a long time ago, a Chinese mandarin who had a daughter of great beauty.

Like all young girls of her estate, she saw no one and lived a secluded life in a high tower in the mandarin's palace. She usually took her seat near the window, to read or embroider, sometimes pausing to look at the river which ran below her, and she dreamed while following it across the plain.

3 From time to time she saw the tiny boat of a fisherman gliding on the calm waters. The man was poor and he often sang. From a distance, she could not see his face, could scarcely distinguish his movements, but she listened to his voice as it rose to where she was. His voice was beautiful and his song sad. 
4 I do not know what sentiments and what dreams the song and the voice made blossom in the heart of the young girl, but we do know that one day the fisherman did not come to the river and she waited for him.

5 She waited several days, she became sick. The doctors could not discover the cause of her illness, her parents became anxious, the illness grew worse, then suddenly, the young girl was cured: the song had returned.

6 The high mandarin organised a search for the fisherman, he had the fisherman placed in the presence of the girl.

7 At her first look, something ended in her. She no longer loved to hear his voice...

8 But the poor fisherman, himself, received a fatal blow from this manifestation. There is an untranslatable word in Annamite to describe the illness he suffered [Om tuong tu]. In French one says amour-maladie, love-sickness, the love that kills, a fatal passion, a tragic love; but none of these expressions exactly translates the Annamite. I think of Racine's heroines, I think of Phèdre discovering the situation, lost, dying, dazzled by the day that disturbs her so profoundly; she must, if I may say so, poison herself if she is to die, while our poor fisherman loves without hope, can no longer live, falls ill and slowly dies, without having any desire to kill himself, without having been killed by anyone else.
$4 \quad$ We cannot know what sentiments or dreams the song and his voice kindled in the young girl's heart; only that, one day when the fisherman did not come to the river; she was surprised to find herself waiting for him until evening.

5 In vain, she waited for him for several days. She finally became sick from waiting.

The doctors could not discover the cause of her illness, her parents were worried, when suddenly the girl recovered: the song had returned.

6 On being informed by a female servant, the high mandarin had the fisherman called and brought him into the presence of his daughter.

$7 \quad$ As soon as she saw him, something in her ended; she no longer loved to hear his voice.

8 But the poor fisherman, he received a fatal blow on seeing her. He was struck down by the disease of "tuong $t u$ ”, love-sickness. Consumed by hopeless love, he withered in silence and died, carrying his secret with him. 
9 The years passed. In accordance with the custom, the fisherman's family exhumed his remains to take them to another place. They found a crystallised mass in the coffin, a sort of large transparent stone. They attached it to the prow of the small boat, and, one day when the mandarin borrowed the boat to cross over the river, he admired the stone, bought it, had it cut to form a beautiful tea cup.

10 Each time one poured tea into the cup, one saw the image of a fisherman in his boat slowly circling the inside of the cup. The young girl learned of this prodigy, wanted to confirm it for herself. She poured a little tea, the image of the fisherman appeared; the young girl remembered him and wept; a tear fell into the cup and the vessel turned to water and dissolved.
9 Many years later, his family exhumed his remains to take them to their final resting place. They found a translucent stone in the coffin. Using it as an ornament, they placed it at the front of his boat. One day, the mandarin passed by, and admired the stone. He bought it, and gave it to a craftsman to shape it into a beautiful teacup.
10 Each time tea was poured into the cup, one saw the image of a fisherman in his boat, slowly sailing around the cup. The mandarin's daughter learnt of this prodigy, and wanted to see it for herself. She poured a little tea, the image of the fisherman appeared: she remembered him and wept ...

A tear fell onto the cup and the cup dissolved.

11 I am sure you can feel how poetic this folktale is. But let me add a few words so that you can better understand it. You will come to know why Annamites love this folktale and you will recognise at the same time a little of the profound soul of that race, who live far from you and who now read the same books as you do.

12 Normally, an Annamite does not think of this folktale without immediately singing the well-known two lines of the verse that alludes to it. I will tell them to you, then I will translate them. Do not laugh if they sound strange, but wait for the explanation:

No tinh chua tra cho ai

Khoi tinh mang xuong tuyen dai chua tan

12 In a well-known Annamite masterpiece, two lines allude to this legend:

Khôi tinh mang xuông tuyên dai chua tan. 


\begin{tabular}{|c|c|c|c|}
\hline 13 & $\begin{array}{l}\text { Here is a word for word translation: } \\
\text { The debt of love has not been repaid; } \\
\text { The stone of love has descended to } \\
\text { the land of the nine springs, it has } \\
\text { not melted. }\end{array}$ & 13 & $\begin{array}{l}\text { As long as the debt of love remains, } \\
\text { In the Land where the Rivers Rise, the } \\
\text { stone of love can never dissolve. } \\
\end{array}$ \\
\hline 14 & $\begin{array}{l}\text { The land of the nine springs is the } \\
\text { other side, they are the oriental Ely- } \\
\text { sian Fields, the plain of asphodels, } \\
\text { the shadow of the immortal myrtles. } \\
\text { And this is what the two lines want } \\
\text { to say, if one notices the logical con- } \\
\text { nections between the propositions, } \\
\text { as one makes the thought more } \\
\text { precise, which is what the French } \\
\text { language requires. }\end{array}$ & 14 & $\begin{array}{l}\text { The Nine Springs, or the Yellow } \\
\text { Springs, are on the other side; they } \\
\text { are our plain of asphodels, the shad- } \\
\text { ow of immortal myrtles. }\end{array}$ \\
\hline 15 & $\begin{array}{l}\text { "When" the debt of love remains } \\
\text { unpaid (or "if" the debt), the stone } \\
\text { of love, even if it descends into the } \\
\text { land of the nine springs, does not } \\
\text { dissolve." }\end{array}$ & & \\
\hline 16 & $\begin{array}{l}\text { One can see that this influences } \\
\text { our story. But what is the precise } \\
\text { meaning of "a debt of love"? What } \\
\text { has not been paid? And to whom } \\
\text { must it be paid? A European mind } \\
\text { would think: it was the young girl } \\
\text { who should have paid the young } \\
\text { man, since he died because of his } \\
\text { love for her, since - and this is the } \\
\text { essential reason - it was by weeping } \\
\text { over the tea cup, on dropping a tear } \\
\text { over this poor crystallised love, that } \\
\text { she made it dissolve. Her pity, her } \\
\text { recognition of this love; I want to } \\
\text { say that she was conscious of the } \\
\text { love to which she had given birth } \\
\text { but which she did not recognise, it } \\
\text { delivered her, granted her, allowed } \\
\text { her to recognise, managed to end } \\
\text { the term of her destiny. }\end{array}$ & 16 & $\begin{array}{l}\text { But what "debt of love" is meant? } \\
\text { Who failed to repay the debt? } \\
\text { One could think the young girl } \\
\text { owed the young man something, } \\
\text { since he loved her to the point of } \\
\text { death, without being repaid by her. } \\
\text { Belatedly, she settled the debt, when } \\
\text { by crying over the poor crystallised } \\
\text { love, she made it melt. The pity that } \\
\text { she felt for his fate; her regrets at } \\
\text { having been the cause of his passing, } \\
\text { must have appeased, beyond death, } \\
\text { the torments of an inconsolable } \\
\text { heart. }\end{array}$ \\
\hline
\end{tabular}


17 This is a pretty interpretation, but you can also think of it in the following way: the young man was destined to love the young woman, but at first his love was ignored by the young girl, never reached her, was not fulfilled in its natural progression. He "had to love her" and, as long as she did not understand this, accepted it, his debt had not been paid to her. There is a second explanation, no less seductive than the first. And an Annamite will tell you this if you take the trouble to consider his opinion. But I think these distinctions and nuances are useless. Besides this, I don't know whether, in seeking out these different meanings, I have given way to the oriental taste for subtlety or if I am obeying the occidental desire for precision. What is certain is that, for an Annamite, the folktale that I have just told you is complete. It has to stop where it ends; we cannot imagine that it could be any other way. No one can tell us if the young girl loved the fisherman when she heard him singing without seeing him.
17 To an Annamite, the folktale can signify more than that. He believes that all love is predestined, all unions are the inescapable consequence of a debt contracted in a past life; when two human beings bind themselves to each other, they are only freeing themselves of a mutual burden.

So the beautiful daughter of the mandarin had to have her fated meeting with the poor fisherman, despite all that separated him from her. When she heard his voice rising from the river, when she then thought day and night about the face she had barely glimpsed, their paths searched for ways by which they might join with each other, and their blind hearts beat in accordance with the rhythm of destiny.

But they were never united in his lifetime. The debt remained and the fisherman could not disappear after his death. What was found in the coffin was not only the material remains of a profound feeling which continued after his body dissolved; it was the whole man, his form beyond the grave, the face of an unrealised destiny which necessarily had to crystallise in view of the necessity of waiting. 
Further, no one can tell us the nature of her feelings when she wept over the translucent teacup in which the reflection of an indistinct dream glided past. No one can try to make us feel moved by the illness and death of this hopeless lover. No one says anything of his pain. What matters is the meeting of two destinies in the broadest sense of the word, the fusion for a certain time of these two destinies, I do not say of these two human lives, since the tears of the woman did not fall for a very long time after the disappearance of the man. The debt of love is not a debt that the man should have paid the woman, it is not a debt that the woman should have contracted by inspiring the man to a fatal love. But their love is nothing more than a form of their common debt, the human debt to life: each of us must pay it when we pursue the difficult path that we must follow on this earth. Besides, human beings do not live just one life, but submit to a circle of successive transformations. Each earthly life has no meaning only in itself, the destiny of each individual is broader than they are and the union of two beings, a man and a woman, is nothing but the meeting of their two destinies, a moment in a chain, a point on the circumference, which is as incomprehensible to them as is the rest of their ephemeral existence, as inescapable for them as the rest of the rest.
Later, the woman came to lean over the diaphanous cup where there glided the reflection of a beautiful vanished dream. She had an intuition of the debt which bound her to the fisherman; she regretted having become aware of her path too late, at a time when she could no longer find true happiness. But she understood that their union must inevitably be accomplished, beyond their ephemeral existences. Perhaps she sensed that a solemn moment was at hand...

The cup received the tear which fell from her eyes and melted there in a communion which liberated them both. 
19 That is the basis on which this folktale rests. If I were wiser, I would show you that it is inspired by Buddhism, I would speak of the influence of such beliefs on the Annamese people, on their conception of life and of love. But I have only wanted to tell you a beautiful story. At least retain its poetic beauty, love it for all you can feel of its delicate sentiment: the voice rising from the river, the sincere and silent passion that survived the dissolution of his body, the tear which freed him. Think of the melodious fisherman when you see a fine porcelain teacup decorated with blue designs. You can say that, for an Annamite, this story is not a folktale, but an historical tale. You can say that this happened in China, a long time ago, but no one will be able to tell you under which emperor, from such and such a dynasty, in this particular place. He believes this more than you believe in Sleeping Beauty. It is not a beautiful folktale to him, it is a true story. For me, even at the age when I scanned the verses of the "Aeneid" in a French high school, I would never have been astonished if I had learned that on the bank of the Great Lake, very near my school, someone had discovered the crystal of love. I would have wondered: "Who will drop the tear which will dissolve this cup?"

\section{Rewriting a Beautiful Vietnamese Folktale}

At the end of his broadcast speech, section 19, Pham confirmed his knowledge of the Chinese origin of the tale. (It is perhaps partly for this reason that the future book is entitled in the plural: Legends from Serene Lands.) Nevertheless, his broadcast retelling completely follows the Vietnamese form of the story and its interpretation. It also includes an added, elaborate 
commentary for its French audience whom he fears might be inclined to scoff at the tale. Certain features remain constant between Pham's two versions (which, for convenience, we will call the Long Version, LV, the Radio talk, and the short version, SV, published in Légendes des terres sereines.). These common features include the fact that the characters have no names; it is the fisherman who contracts love sickness and dies; his body is dug up for further reburial; a lump of crystal is discovered and made into a tea-cup; the girl eventually receives the cup and sees the boatman sailing around the cup; she weeps and the cup dissolves. The lines from the national epic, The Tale of Kieu, are described simply as some "well known verses" being derived from an unnamed "well-known Annamite masterpiece."

There are also differences. They are significant in themselves and also crucial for Khiem's development as a writer.

To start with, SV has no Introduction. In LV1, Khiem creates a narrator's personality for himself which is both French and Vietnamese: "an old professeur who teaches Greek, Latin, and French to young students like you and to Annamites of your age." He was thirty at the time but this authoritative position gives him mastery over French pupils (and French listeners in general). It also relates him to Vietnamese pupils, placing the Vietnamese colonial subjects on the same level as their colonial peers. In fact, it elevates Vietnamese culture above French culture because this folktale is "the most beautiful" of all the stories he has heard beside the Seine and the Red River. He is further able to claim a special position with regard to the tale because he doesn't know when he heard or read it, and when he first makes its acquaintance. It is ageless and a part of his very identity. He sees no need to make these claims in the SV.

His authority is strengthened because he is addressing the French in French. LV2 recognises their ignorance. "You need to know . . ." he says. Then he explains the isolation of "the daughters of high mandarins" and justifies the custom: "They did not suffer because things had always been this way and that very isolation was a part of their condition." SV2 (there is no SV1) simply accepts her solitary state and distracts the listener's attention by describing her serious activities: reading and embroidering. She is young, so 
of course she dreams while "following the river across the plain." Another version of the tale, by a French author of Vietnamese descent, Minh Tran Huy (2008), adds other, more frivolous details: she read books of poetry and, while watching the river, "dreamed of following its silvery waters to far-off places and of the people she might meet there" (133). From the start, Khiem's second version is understated and, like himself, even somewhat ascetic.

Next, LV4 and SV4 both agree on her hearing the song of a poor fisherman. LV4 includes the negative comment that the rice-fields were "monotonous" which he omits from the SV perhaps to avoid offence. The next sections run in a parallel direction: the girl responds to his singing and waits for him. When he does not come, LV 6 and SV6, she falls ill. The doctors could cannot cure her. ${ }^{4}$

When the fisherman returns, the girl recovers. In SV7, it is the emotional touch of a woman's intuition that indicates to the mandarin that the fisherman has made an impression on the girl. The father calls the fisherman and, in both accounts, the girl looks at the boatman and no longer loves his voice. It is commonly accepted in Vietnam that the man is not just poor but, in fact, he is exceedingly ugly. Khiem does not introduce this possibility as an explanation; the break is just something that happens. So the inevitability adds to the sadness of the tale in both versions.

The effect of her response overwhelms the man. He is struck down by the fatal disease of "love sickness." SV9 gives only the Vietnamese term for this condition, tuong tu. Although LV9 describes this term as "untranslatable", it does provide a French equivalent, amour-maladie, and glosses over it several times: "love-sickness, the love that kills, a fatal passion, a tragic love." In fact Khiem goes further which his status as an agrége of the ENS entitles him to do. He compares the young girl's condition with that of Racine's Phèdre for his French audience. Again he matches French culture and criticises it: Phèdre's death is deliberate and unpleasant; the fisherman's condition is one of slow decline-he does not kill himself and no one else does so either. It is a sad but not malicious or violent ending.

Section 10 deals with the discovery of "a translucent stone" (SV) or "crystallised mass" (LV) in his coffin. The shorter version accepts a cultural 
practice that the French might find unpleasant: "his family exhumed his remains" many years later. The custom was to exhume the dead three years after their death, wash the bones, and re-inter them again so that the soul may live in peace (Lamb 195). The LV explains the practice simply as the need to take the remains "to another place," a sop to the potential revulsion of his European audience. However, in both versions there is no description of the stone but there is no suggestion that it is blood-red.

The mandarin has the stone made into a "beautiful cup" (LV 10 and SV10). Inside the cup, one can see the image of a fisherman in his boat. The girl sees the image, remembers the fisherman, and weeps. A tear falls onto the cup and it dissolves (LV 11 and SV11). These sections, four to eleven, form the core of the story and do not change. The girl finally recognises that she has been frivolous and caused great harm to the man whom she so much admired from a distance and who died because of her.

Again, in LV 12, Khiem recognises the sensitivity of his French audience: "I am sure you can feel how poetic this folktale is," he says (LV 12), while also indicating their ignorance. His aim is to help them understand "the profound soul of that race who live far from you and who now read the same books as you do", that is, whose level of civilisation is at least equal to yours but whom you despise. It is a subtle example of the empire writing back.

But the Vietnamese not only share the tale with each other; they also respond to it with poetry. LV13 does not name the source of the two lines quoted. SV 13 attributes them to "a well-known Annamite masterpiece" which he also does not name-The Tale of Kieu. As I have mentioned elsewhere, this is rather like describing Shakespeare as "a well known English poet" (Aveling, "The Absent Father" 9). He recognises the French prejudice towards Vietnamese language and literature (LV 13) and cautions his listeners not to laugh if the lines "sound strange" but to wait for their explanation. In SV 14, he simply translates the lines. His audience has changed and the Annamite audience have respect for their own culture.

Both versions provide a commentary on the verse and by implication on the story. SV 14 makes two possible steps. The girl may have owed 
the fisherman something but there is more than that. In accordance with Vietnamese culture, all love is predestined. The couple were bound to each other in a past life. Despite their different social statuses, they had to meet. Their love survived beyond the grave and when the girl wept over the cup, her previous loving feelings were accepted and the bond between them was once more affirmed .... and dissolved.

LV 14 on the afterlife is far more complicated. Like SV 14, it glosses over the "land of the nine springs" in Greek mythological terms: "the other side ... our plain of asphodels, the shadow of immortal myrtles". The lines avoid the horrors of the Vietnamese myth of the river which the dead must cross facing the nine vicious hounds of hell and the complex philosophy of the Buddhist doctrine of rebirth. Khiem notes, in passing, the stultifying effect of French rationality, which is implicit in the French language itself.

LV15 continues this exploration of the deficiencies of "the European mind". The young girl may have been in debt to the fisherman. This is a "pretty explanation." But there is "a seductive explanation" which the Vietnamese will share "if you take the trouble to consider his opinion." (Obviously Khiem did not expect that all Europeans would.) It goes beyond "the occidental desire for precision." The European view is, in fact, sentimental: it imagines what the girl felt, what the man felt, but it does not realise that the story does not describe these. The actual debt is the result of their spiritual condition, what Buddhism describes as the result of endless reincarnations, as souls are born and reborn, meet briefly, then separate again.

Although the radio broadcast is aimed squarely at them, Khiem does not expect his European audience to understand these matters (LV 19). He is pleased if they can just retain its poetic quality-this is what Vietnam has to offer cold rationality. He admits that this is a myth, one that is not true-just as "Sleeping Beauty" is not true, although the Aeneid might be! It is the same comment he made in his presentation of another Vietnamese folktale to the French, the story of Tu Thuc (see Aveling, "Shadow" 19-20). He does this for the same reason: to claim equality with the colonial master and then to push for the superiority of a people whom the French may at first consider 
inferior to themselves. With an indigenous audience, the telling of the tale is a sharing between equals. The conciseness and gentle melancholic tone is characteristic of Khiem's mature style in the Légendes des terres sereines We may see these as the fruits of a post-colonial negotiation of Khiem's own identity: Vietnamese, French-educated, but the proud voice of his people and their culture.

\section{Conclusion}

"The Princess and the Fisherman Love's Crystal" is a variable Vietnamese version of an ultimately Chinese folktale. The long version we have been reading here, a radio talk given in France by the Vietnamese scholar Pham Duy Khiem, was directed towards a French-speaking audience in France. It explains the various details of the story which the French would not understand, and carries the added burden of establishing the narrator as a figure worthy of respect and aware of the lack of respect that the French commonly have towards Vietnamese culture. The short version is concise and assured, allowing the indigenous audience greater emotional freedom as they accept their own culture unreservedly and without any explanation. The two versions conform to Pham Duy Khiem's practice when he rewrites other stories-“The Absent Father" (Aveling, "The Absent Father") and "Tu Thuc" (Aveling, "Shadow"). In each of these tales, Khiem moves from a complex folktale intended to entertain and educate the French readers towards a simpler, more direct style of narration, without condescension or any surrounding commentary. There is a confidence about the story line of the final "Love's Crystal” presented in Légendes des terres sereines (1942). Khiem has kept the story, simplified it, added to its pathos, and provided a brief but tragic commentary. The maturity he displays in the book of Légendes is striking and depends, in part, on a rejection of the culturally ignorant and emotionally insensitive colonial master.

The message of "Love's Crystal" is one Khiem took seriously enough to make it the final commentary to his one published novel Nam et Sylvie (1957), the story of the ill-fated love of a Vietnamese normalien for a French girl. They are lovers in Paris but he feels unable to take her back to the 
colony because of the discrimination she will meet as the wife of a native. Nonetheless, "[n]othing is ever finished in the world of the heart," Nam decides. "Or rather it never ceases to be," he continues, quoting another version of the Kieu poem:

Once you have crossed the river together, an acquaintance has been made; Once you have spent a day together, that creates a debt and a common fidelity (Pham Duy Khiem 242).

This is the Chinese version of the story and the traveller never returnsas he knew he would not. He may weep but it cannot restore the princess to life. The cup melts forever. 


\section{Notes}

1. This is a revised version of an article previously published in Portal, University of Technology, Sydney, vol. 15, no. 1-2 2018. Reprinted with permission.

2. This paragraph draws extensively on Mowry (1983).

3. This is a collaborative translation. My thanks to Dr. Lintao (Rick) Qi, Monash University for finding the original text, and to Professor Anne McLaren, Melbourne University and Dr. Xu Yuzeng, La Trobe University for helping translate it. On collaborative translation, see my "On Translating from Languages One Does Not Know: Faking the Pumpkin?” in Translation, Transnationalism, World Literature, edited by Francesca Benocci and Marco Sonzogni, Novi Liguri: Joker, pp. 45-63.

4. I have taught this story in the SV with Vietnamese students, by the way, and they found the mention of "doctors" strange. But then they found the whole of Khiem's 'translation' unfamiliar and somewhat unpleasant. Today both versions are "exotic" and even the SV is still distant from the familiar story that the Vietnamese know. 


\section{Appendix: The Original Chinese Text}

\section{化铁}

昔有一商, 美姿容, 泊舟于西河下。而岸上高楼中, 一美女相 视月余, 两情已契, 为十目十手所隔, 弗得遂愿。迨后其商货尽 而去, 女思成疾而死。父焚之, 独心中一物, 不毁如铁。出而磨 之, 照见其中有舟楼相对, 隐隐如有人形。其父以为奇, 藏之。 后商复来访, 其女已死, 痛甚。咨诹博询, 备得其由。乃献金于 父, 求铁观之, 不觉泪下成血, 血滴于心上, 其心即灰矣。 


\section{Works Cited}

Aveling, Harry. "The Absent Father: A Vietnamese Folktale and its French Shadows." GEMA Online Journal of Language Studies, vol. 17, no. 2, 2017, pp. $1-14$.

---. "Shadow of the Absent Father: Pham Duy Khiem, Politics and Plagiarism."

Translation Review, vol. 100, no. 1, 2018, pp. 16-27.

Huynh Sanh Thong, editor. Nguyen Du, The Tale of Kieu. Yale UP, 1983.

Hua-yuan Li Mowry. Ch'ing-Shih and Feng Meng-long. 1976. University of California, Berkeley, PhD dissertation.

---. Chinese Love Stories from 'Ch'ing-Shih'. Archon Books, 1983.

Nan Ma Hartmann. From Translation to Adaptation: Chinese Language Texts and Early

Modern Japanese Literature. 2014. Columbia University, PhD dissertation.

Nguyen Van Vinh, editor. Nguyen Du, Kim Vân Kièu. NVB Van Nghe, 2000.

Pham Duy Khiem. “Une légende Annamite.” Mélanges. Taupin, 1937, 1942.

---. Légendes des terres sereines. Taupin, 1942.

---. Nam et Sylvie. Plon. 1957.

Thang, Vo Van, and Jim Lawson. Vietnamese Folktales. NXB Da Nang, 2002. 